\title{
Bulk density and water tensions in the soil on corn root production
}

\author{
João A. S. Nunes ${ }^{1}$, Edna M. Bonfim-Silva ${ }^{1} \&$ Tonny J. A. da Silva ${ }^{1}$ \\ ${ }^{1}$ Universidade Federal de Mato Grosso/Instituto de Ciências Agrárias e Tecnológicas. Rondonópolis, MT. E-mail: joaoangelo_jaciara@hotmail.com; \\ embonfim@hotmail.com (Corresponding author); tonnyjasilva@hotmail.com
}

Key words:

Zea mays

soil compaction

soil management

\begin{abstract}
A B S T R A C T
Inadequate management of soil and water can cause changes in soil physical characteristics, resulting in lower root development. Thus the objective of the present study was to evaluate the dry matter production of corn roots under combinations of levels of bulk density and water tension in the soil. The experiment was conducted in a greenhouse in a randomized block design, based on a modified central composite design of a $5^{2}$ fractional factorial scheme, of combinations of bulk densities (1.0, 1.2, 1.4, 1.6 and $1.8 \mathrm{Mg} \mathrm{m}^{-3}$ ) and water tensions in the soil $(10,20,3040$ and $50 \mathrm{kPa})$, resulting in 13 treatments with four replicates. An Oxisol collected in the layer of 0-0.2 $\mathrm{m}$ was used. The pots were made of PVC (polyvinyl chloride) tube with compacted soil in the middle layer. The tensiometers were installed at a depth of $0.15 \mathrm{~m}$, remaining in the central region of the compacted layer. The experiment was collected 104 days after sowing. Root dry matter production of corn was limited by increased water stress and bulk density.
\end{abstract}

\section{Palavras-chave:}

Zea mays

compactação do solo

manejo do solo

\section{Densidades e tensões de água no solo na produção de raízes de milho}

\section{R E S U M O}

O manejo inadequado do solo e da água pode ocasionar alterações nas características físicas do solo resultando em menor desenvolvimento radicular. Assim, objetivou-se, no presente estudo, avaliar a produção de massa seca de raízes de milho com combinações de níveis de densidade e tensões de água no solo. O experimento foi realizado em casa de vegetação utilizando-se o delineamento experimental de blocos casualizados em arranjo fatorial baseado em desenho experimental composto central modificado de um fatorial $5^{2}$ fracionado por combinações de densidades do solo $\left(1,0 ; 1,2 ; 1,4 ; 1,6\right.$ e $\left.1,8 \mathrm{Mg} \mathrm{m}^{-3}\right)$ e tensões de água no solo $(10,20,30,40$ e $50 \mathrm{kPa})$ resultando em 13 tratamentos com quatro repetições. Foi utilizado um Latossolo Vermelho coletado de 0,0 a 0,2 $\mathrm{m}$ de profundidade. Os vasos foram constituídos de tubo de PVC (policloreto de vinila) com solo compactado na camada intermediária. Os tensiômetros foram instalados na profundidade de $0,15 \mathrm{~m}$ permanecendo assim na região central da camada compactada. O experimento foi coletado aos 104 dias após a semeadura. A produção de massa seca de raízes na cultura do milho foi limitada pelo aumento das tensões de água e densidade do solo. 


\section{INTRODUCTION}

Corn (Zea mays L.) is a diploid, allogamous species that belongs to the Poacea family, originated in Mexico and Central America. The largest producers are the United States, with $36.9 \%$ of the total (2013/14 season), China (22\%) and Brazil (7.5\%), which are also the largest consumers of this crop (EMBRAPA, 2013a).

The intensification of production processes in the agricultural sector, due to technological advancements, promotes an increase in the traffic of agricultural machines, often resulting in worsening of degradation of soil physical quality, especially in soils with high clay contents (Severiano et al., 2009) diagnosed by the increase in the level of soil compaction (Bergamin et al., 2010).

Compaction is the result of the proportional reorganization of charges or pressures exerted on the soil (Souza et al., 2008) and can be defined as a gradual, dynamic process, which alters the structure and reorganizes particles and their aggregates. With the increase in soil bulk density and reduction of total porosity and macroporosity, there is a reduction of soil water infiltration, air movement, availability of nutrients in the soil and penetration and ramification of roots, due to excessive mechanical resistance and deficient aeration (Jimenez et al., 2008; Freddi et al., 2009a).

Studies have shown the advantages of considering the water tension in the management of soil moisture, estimating it with tensiometers (Wang et al., 2007; Rivera-Hernández et al., 2009), which allows determining the water tension at which the soil must be maintained for a crop, in soils with different physical properties.

Through its roots, the corn plant absorbs water and nutrients for its development; thus, it needs a vigorous root system for good yield. Most researches emphasize the development of plant shoots, leaving the roots as an occult component and not addressing the interdependence between these two plant parts (Bonfim-Silva \& Monteiro, 2010).

In this context, studies aiming to evaluate the damages in agricultural crops caused by water stress and physical impairments in the soil, as well as the occurrence of both, are essential. This study aimed to evaluate root dry matter production of corn under combinations of levels of bulk density and water tensions in the soil.

\section{Material AND Methods}

The experiment was conducted in greenhouse, using the corn hybrid 2B688PW. The experimental design was randomized blocks, with five soil bulk densities (1.0, 1.2, 1.4, 1.6 and $\left.1.8 \mathrm{Mg} \mathrm{m}^{-3}\right)$ and five soil water tensions (10, 20, 30, 40 and $50 \mathrm{kPa})$, in a $5^{2}$ factorial scheme, totaling 13 treatments (1.0 x $10 ; 1.0$ x $30 ; 1.0$ x 50; 1.2 x 20; 1.2 x 40; 1.4 x 10; 1.4 x $30 ; 1.4$ x $50 ; 1.6 \times 20 ; 1.6 \times 40 ; 1.8 \times 10 ; 1.8 \times 30 ; 1.8 \times 50)\left(\mathrm{Mg} \mathrm{m}^{-3} \mathrm{x} \mathrm{kPa}\right)$ and four replicates, which resulted in 52 experimental plots.
This design is a fractionated factorial based on the modified central composite design (Littell \& Mott, 1975).

The soil used in the experiment was a Oxisol (EMBRAPA, $2013 \mathrm{~b}$ ) collected in the layer of $0-0.2 \mathrm{~m}$ in area under Cerrado vegetation, in the city of Rondonópolis-MT. Its chemical and granulometric characteristics (Table 1) were determined according to EMBRAPA (1997). Before compaction, the soil was fertilized with phosphorus $\left(\mathrm{P}_{2} \mathrm{O}_{5}\right)$ and potassium $\left(\mathrm{K}_{2} \mathrm{O}\right)$, using 150 and $250 \mathrm{mg} \mathrm{dm}^{-3}$, in all the soil volume of each experimental plot, supplied by single superphosphate and potassium chloride, respectively. This fertilization aimed to guarantee a homogeneous distribution of these nutrients along the entire soil profile even after compaction, which was performed at sowing.

Base saturation was increased to $60 \%$ and, after applying dolomitic limestone (RNV $80.3 \%$ ), the soil remained in incubation for 30 days.

The pots were made of PVC (polyvinyl chloride) tubes with $0.2 \mathrm{~m}$ of external diameter, width of $2.5 \mathrm{~mm}$ and height of 0.1 $\mathrm{m}$. Three rings were stacked and each experimental plot was $0.3 \mathrm{~m}$ high. The rings were fixed together using adhesive tape and an anti-aphid screen was fixed at the bottom of each pot, with the aid of a car inner tube. The rings were placed on plastic plates in order to avoid the loss of soil and water by the system.

The soil was compacted using a P15 ST hydraulic press. Bottom and top rings were filled with soil at the density of 1.0 $\mathrm{Mg} \mathrm{m}^{-3}$, while central rings were filled with soil compacted at the density levels of the treatments $(1.0,1.2,1.4,1.6$ and 1.8 $\mathrm{Mg} \mathrm{m}^{-3}$ ), thus having a compacted layer of $10 \mathrm{~cm}$.

Eq. 1 was used to determine the mass of dry soil used in each compaction level, based on the relationship with density, i.e., mass of dry soil and total volume.

$$
\mathrm{Ds}=\frac{\mathrm{MS}}{\mathrm{VT}}
$$

where:

MS - mass of dry soil, Mg;

VT - total volume of the ring, $\mathrm{m}^{3}$; and,

Ds - soil bulk density, $\mathrm{Mg} \mathrm{m}^{-3}$.

In addition, the same soil bulk density treatments were also applied in $50-\mathrm{cm}^{-3}$ volumetric rings (diameter $=4.90 \mathrm{~cm}$; height $=2.66 \mathrm{~cm}$ ) for the characterization and determination of soil water retention curve, resistance to penetration and soil micro and macroporosity, as a function of the density of each treatment.

The volumetric rings were sealed at the bottom using rubber bands and TNT (nonwoven fabric) and arranged in a container with water until two thirds of its height, where they remained for $24 \mathrm{~h}$ for soil saturation. Then, the rings were subjected to tensions of 7, 20,28,33,50,100,200, 500 and $1500 \mathrm{kPa}$, using Richards' pressure plate apparatus.

Table 1. Chemical and granulometric characteristics of the Oxisol in the layer of 0-0.2 $\mathrm{m}$

\begin{tabular}{|c|c|c|c|c|c|c|c|c|c|c|c|c|c|}
\hline \multirow{2}{*}{$\begin{array}{c}\mathrm{pH} \\
\mathrm{CaCl}_{2}\end{array}$} & $\mathbf{P}$ & K & $\mathrm{Ca}$ & $\mathrm{Mg}$ & Al & $\mathrm{H}$ & SB & CEC & \multirow{2}{*}{$\begin{array}{l}\mathbf{V} \\
\%\end{array}$} & \multirow{3}{*}{$\begin{array}{c}\text { OM } \\
\text { g dm } \\
22.7\end{array}$} & \multirow{2}{*}{\multicolumn{3}{|c|}{$\frac{\text { Silt }}{\mathrm{g} \mathrm{kg}^{-1}}$}} \\
\hline & \multicolumn{2}{|c|}{$\mathrm{mg} \mathrm{dm} \mathrm{dm}^{-3}$} & \multicolumn{6}{|c|}{$\mathrm{cmol}_{\mathrm{C}} \mathrm{dm}^{-3}$} & & & & & \\
\hline 4.1 & 2.4 & 28 & 0.3 & 0.2 & 1.1 & 4.2 & 0.6 & 5.9 & 9.8 & & 549 & 84 & 367 \\
\hline
\end{tabular}


Total porosity, macro and microporosity (Table 2) were determined using the methodology of EMBRAPA (1997), in which macro and microporosity determination is based on the application of a tension of $6 \mathrm{kPa}$ in the Richards' pressure plate apparatus. Particle density was determined through the volumetric flask method and was equal to $2.33 \mathrm{~g} \mathrm{~cm}^{-3}$.

Soil resistance to penetration was determined using a tabletop penetrometer (MA 933) with tip diameter of $3 \mathrm{~mm}$ and velocity of $30 \mathrm{~mm} \mathrm{mim}^{-1}$, in three replicates. Soil resistance to penetration was determined for each soil bulk density, at the water content corresponding to the tension of $10 \mathrm{kPa}$ (Freddi et al., 2007), in $50-\mathrm{cm}^{-3}$ volumetric rings.

The results of water retention were interpolated by the equation of Genuchten (1980) (Eq. 2) with the aid of the computational program Soil Water Retention Curve (version 3.0) developed by Dourado Neto et al. (2000), who described the behavior of soil water contents as a function of the tension (Table 3).

$$
\theta_{\mathrm{v}}=\theta_{\mathrm{r}} \frac{\theta_{\mathrm{s}}-\theta_{\mathrm{r}}}{\left[1+\left(\alpha\left|\Psi_{\mathrm{m}}\right|\right)^{\mathrm{n}}\right]^{\mathrm{m}}}
$$

where:

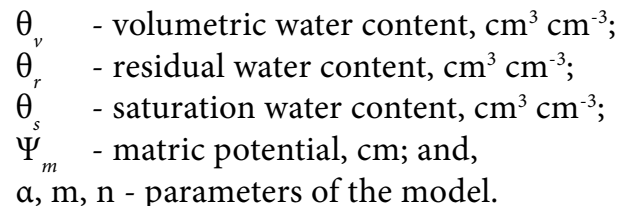

Soil moisture was maintained using tensiometers installed in the pots, in order to control the water content at the depth of $0.15 \mathrm{~m}$, in the central region of the compacted layers. Tensiometers were installed in all the experimental plots. Soil water tension was monitored using a digital tensiometer with sensitivity of $0.1 \mathrm{kPa}$, with two readings per day (from $8 \mathrm{~h} 00$ min to $14 \mathrm{~h} 00 \mathrm{~min}$ ).

Table 2. Values of macroporosity, microporosity, total porosity and soil resistance to penetration for the evaluated soil densities

\begin{tabular}{ccccc}
\hline $\begin{array}{c}\text { Soil bulk } \\
\text { density } \\
\left(\mathbf{M g ~ m}^{-3}\right)\end{array}$ & $\begin{array}{c}\text { Total } \\
\text { porosity }\end{array}$ & Microporosity & Macroporosity & $\begin{array}{c}\text { Resistance } \\
\text { to penetration } \\
\text { (MPa) }\end{array}$ \\
1.0 & 0.57 & 0.30 & 0.27 & 0.19 \\
1.2 & 0.48 & 0.27 & 0.22 & 0.26 \\
1.4 & 0.40 & 0.26 & 0.14 & 1.14 \\
1.6 & 0.31 & 0.21 & 0.11 & 2.22 \\
1.8 & 0.23 & 0.22 & 0.01 & 6.76 \\
\hline
\end{tabular}

Table 3. Values of the parameters determined by the computational program Soil Water Retention Curve for each soil bulk density

\begin{tabular}{|c|c|c|c|c|c|}
\hline $\begin{array}{l}\text { Soil bulk density } \\
\qquad\left(\mathrm{Mg} \mathrm{m}^{-3}\right)\end{array}$ & $\begin{array}{l}\theta \mathrm{r} \\
(\mathrm{cm}\end{array}$ & $\begin{array}{c}\theta S \\
\left.m^{-3}\right)\end{array}$ & A & m & n \\
\hline 1.0 & 0.000 & 0.468 & 0.0573 & 0.5724 & 0.3545 \\
\hline 1.2 & 0.000 & 0.303 & 0.0798 & 0.0197 & 6.2171 \\
\hline 1.4 & 0.000 & 0.297 & 0.0595 & 0.0294 & 5.2632 \\
\hline 1.6 & 0.000 & 0.274 & 0.0418 & 0.0384 & 2.3057 \\
\hline 1.8 & 0.000 & 0.286 & 0.0558 & 0.0061 & 5.4997 \\
\hline
\end{tabular}

$\theta_{r}$ - residual water content, $\mathrm{cm}^{3} \mathrm{~cm}^{-3} ; \theta_{s}$ - saturation water content, $\mathrm{cm}^{3} \mathrm{~cm}^{-3} ; \mathrm{A}, \mathrm{m}, \mathrm{n}$ parameters of the model
Water management in the treatments began 30 days after sowing (moment of irrigation), based on the evaluation of soil water tension. Irrigation was necessary whenever each tensiometer reached the proposed tension. The volume of water applied through irrigation was calculated based on the soil water retention curve and all the irrigations were performed in order to bring the soil to field capacity $(10 \mathrm{kPa})$. Based on the observed tensions, the correspondent water contents were calculated using the soil water retention curve, according to soil bulk density. The replenishment volume was calculated using Eq. $3\left(1.0 \mathrm{Mg} \mathrm{m}^{-3}\right)$ and Eq. 4 (1.2 to $\left.1.8 \mathrm{Mg} \mathrm{m}^{-3}\right)$.

$$
\mathrm{V}=(\theta \mathrm{cc}-\theta \text { actual }) \times 9000
$$

$\mathrm{V}=\left[\left(\theta \mathrm{cc}_{1.0}-\theta \mathrm{actual}_{1.0}\right) \times 6000\right] \times\left[\left(\theta \mathrm{cc}_{\text {int }}-\theta \mathrm{actual}_{\text {int }}\right) \times 3000\right]$

where:

$\mathrm{V}$ - volume of water, $\mathrm{cm}^{3}$;

$\theta c c$ - water content at field capacity, $\mathrm{cm}^{3} \mathrm{~cm}^{-3}$;

$\theta$ actual - water content at the tension of irrigation, $\mathrm{cm}^{3} \mathrm{~cm}^{-3}$;

$\theta c_{1.0}$ - water content at field capacity (top and bottom layers), $\mathrm{cm}^{3} \mathrm{~cm}^{-3}$;

$\theta$ actual $_{1.0}$ - water content at the tension of irrigation (top and bottom layers), $\mathrm{cm}^{3} \mathrm{~cm}^{-3}$;

$\theta c c_{\text {int }}$ - water content at field capacity (compacted layer), $\mathrm{cm}^{3} \mathrm{~cm}^{-3}$

actual $_{\text {int }}$ - water content at the tension of irrigation (compacted layer), $\mathrm{cm}^{3} \mathrm{~cm}^{-3}$;

3000 - soil volume in the pot (compacted layer), $\mathrm{cm}^{3}$;

6000 - soil volume in the pot (top and bottom layers), $\mathrm{cm}^{3}$; and, 9.000 - pot volume, $\mathrm{cm}^{3}$.

Twenty seeds were planted in each experimental plot at the depth of $3 \mathrm{~cm}$. Thinnings were performed at 6,9 and 11 days after sowing, leaving 5,2 and 1 plant per pot after each thinning.

Nitrogen fertilization was performed in three applications (50 $\mathrm{mg} \mathrm{dm}^{-3}$ ) at 10, 33 and 63 days after sowing, which corresponded to the vegetative stages $\mathrm{V} 3, \mathrm{~V} 8$ and $\mathrm{V} 12$, respectively. The total nitrogen fertilization was equal to $150 \mathrm{mg} \mathrm{dm}^{-3}$, supplied using urea, and the date of its application was determined based on the vegetative stage of the crop. Fertilization with micronutrients was performed in a single application, 10 days after sowing, using $1.39 \mathrm{mg} \mathrm{dm}^{-3}$ of $\mathrm{H}_{3} \mathrm{BO}_{3} ; 2.61 \mathrm{mg} \mathrm{dm}^{-3}$ of $\mathrm{CuCl}_{2} .2 \mathrm{H}_{2} \mathrm{O} ; 7.79 \mathrm{mg}$ $\mathrm{dm}^{-3}$ of $\mathrm{ZnSO}_{4} .7 \mathrm{H}_{2} \mathrm{O}$ and $0.36 \mathrm{mg} \mathrm{dm}{ }^{-3}$ of $\mathrm{MoO}_{3}$.

The experiment was collected 104 days after sowing. Roots were separated according to the soil layer $(0.0-0.1,0.1-0.2$ and 0.2-0.3 m) and washed in running water to remove all the soil. Then, they were dried in open environment, placed in paper bags and taken to a forced-air oven at $65{ }^{\circ} \mathrm{C}$ for $72 \mathrm{~h}$. After drying, the following variables were determined: dry matter for each soil layer, dry matter of adventitious roots and total root dry matter.

All the results received statistical treatment with response surface analysis using the program Statistical Analysis System. Analysis of variance was initially performed for the combinations of soil bulk densities and water tensions, according to the significance of the interaction of these doses in the $\mathrm{F}$ test. Since the interaction of soil bulk densities $\mathrm{x}$ 
water tensions was not significant, first- and second-degree regressions were applied using the GLM (generalized linear model) function at 0.05 probability level.

\section{Results AND Discussion}

There was no interaction for roots in any of the evaluated layers, as well as for dry matter of adventitious roots and total root dry matter. There was isolated effect for soil water tensions and bulk densities, as also observed by Rosolem et al. (1999).

Soil bulk density significantly influenced root dry matter production in all the analyzed variables, except in the layer of 0-0.1 m. On the other hand, irrigation based on water tensions did not promote significant difference in root dry matter production in the layers of 0.1-0.2 and 0.2-0.3 m.

The influence of soil bulk density on root dry matter in the layer of 0.1-0.2 m (Figure 1A) and layer of 0.2-0.3 m (Figure 1B), dry matter of adventitious roots (Figure 1C) and total root dry matter (Figure 1D) caused a decreasing linear response, with maximum productions of $14.92,5.84$ and $62.67 \mathrm{~g} \mathrm{plant}^{-1}$, respectively. In the layer of $0.2-0.3 \mathrm{~m}$, there was a quadratic fit, with maximum production $\left(19.97 \mathrm{~g} \mathrm{plant}^{-1}\right)$ at the soil density of $1.21 \mathrm{Mg} \mathrm{m}^{-3}$ (Figure 1B and Figure 2).

In the layer of $0.0-0.1 \mathrm{~m}$, there was no significant effect of soil bulk density, probably because root development was not impaired by the soil from the depth of $0.1 \mathrm{~m}$ on. The same result was obtained by Silva (2004), who observed no significant difference in root production of corn in the layer above the compacted one. However, in the layers of 0.1-0.2 and 0.2-0.3 $\mathrm{m}$, there was difference in root dry matter production as a function of soil bulk density. Root production decreased in the layer in which the treatments were applied (0.1-0.2 m), because of the increase in resistance to penetration caused by impedance resulting from higher soil densities. The mean at the density of $1.8 \mathrm{Mg} \mathrm{m}^{-3}$ was superior to the mean at the density of $1.6 \mathrm{Mg} \mathrm{m}^{-3}$, despite the higher resistance to penetration. However, according to Figure 2, there was a small disruption in the first $0.02 \mathrm{~m}$ in the intermediate layer at the density of 1.8 $\mathrm{Mg} \mathrm{m}^{-3}$, probably because there was no "mirror" effect (shiny, smooth surface due to excessive pressing) during soil pressing.

In the layer of $0.2-0.3 \mathrm{~m}$, at the soil density of $1.8 \mathrm{Mg} \mathrm{m}^{-3}$, roots were not able to break the compacted layer and root production was approximately $10 \mathrm{~g} \mathrm{plant}^{-1}$ lower than that at the density of $1.6 \mathrm{Mg} \mathrm{m}^{-3}$. This difference results from the values of soil resistance to penetration, which were equal to 6.76 and $2.22 \mathrm{MPa}$, respectively. Still in the bottom layer of the experimental plot, a regression adjustment different from those of the other root production variables can be observed, probably due to the alteration in corn root anatomy at different values of resistance to penetration, caused by the increase in the levels of soil bulk density (Bergamim et al., 2010). This was confirmed by Streck et al. (2004), who observed that soil compaction increases the values of soil bulk density and resistance to penetration and reduces total porosity. This effect is more pronounced on macroporosity, which was only $0.01 \mathrm{~m}$ $\mathrm{m}^{-3}$ at the density of $1.8 \mathrm{Mg} \mathrm{m}^{-3}$. The observed value is limiting for aeration and favors the increase in resistance to penetration, even under conditions of water availability. The soil density
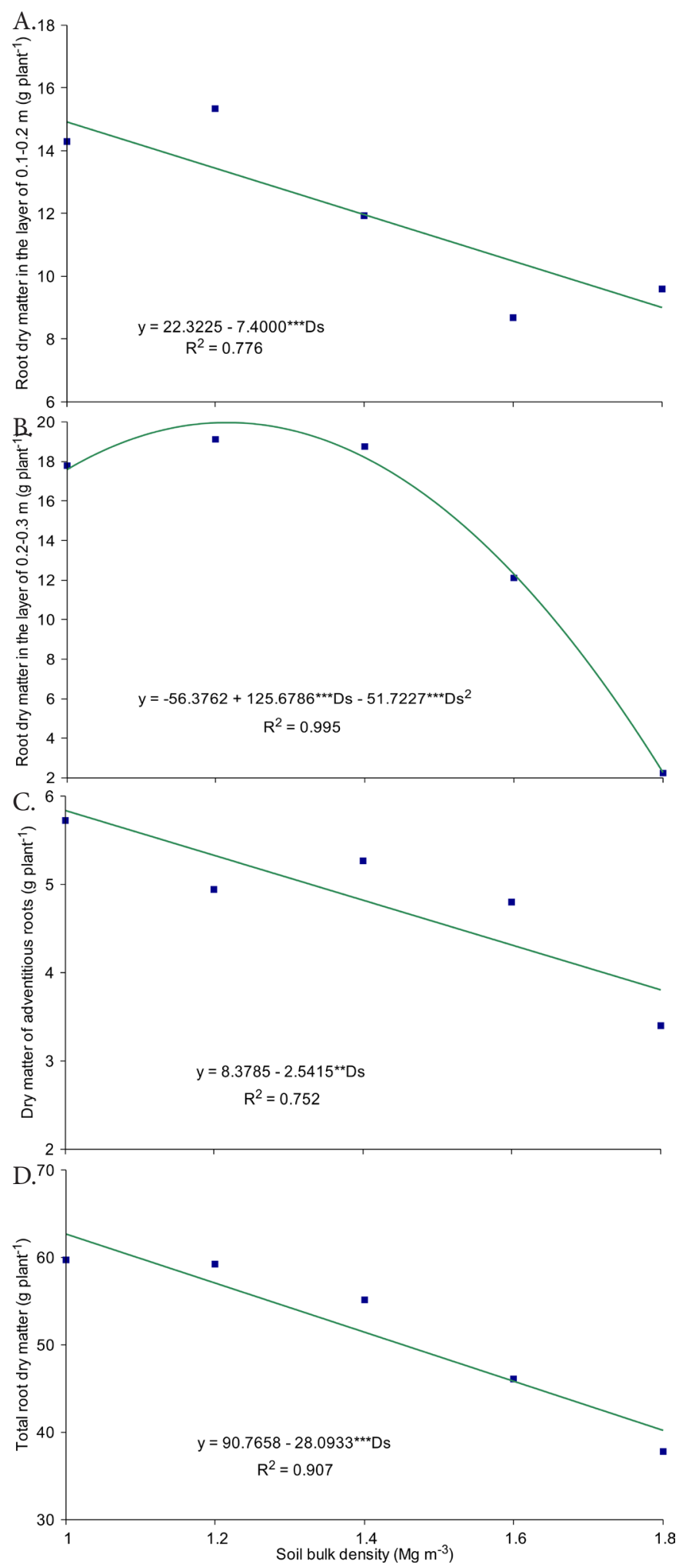

Figure 1. Root dry matter of corn in the layers of 0.1-0.2 $\mathrm{m}(\mathrm{A})$ and $0.2-0.3 \mathrm{~m}(\mathrm{~B})$, and dry matter of adventitious roots (C) and total root dry matter (D), as a function of soil density levels

of $1.6 \mathrm{Mg} \mathrm{m}^{-3}$ resulted in macroporosity of $0.11 \mathrm{~m} \mathrm{~m}^{-3}$, which is $0.01 \mathrm{~m} \mathrm{~m}^{-3}$ higher than that limiting for soil aeration. This differs from the result reported by Freddi et al. (2009b), who observed, through the definition of least limiting water range, densities above $1.40 \mathrm{Mg} \mathrm{m}^{-3}$ for a Oxisol, which would result in aeration porosity of $0.10 \mathrm{~m}^{3} \mathrm{~m}^{-3}$ (limiting for the root system) with increase in water content to field capacity. 
A.

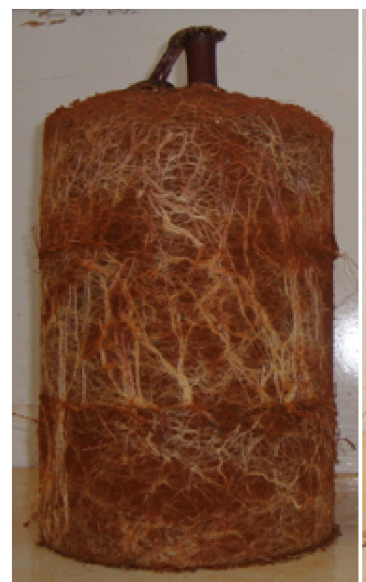

B.

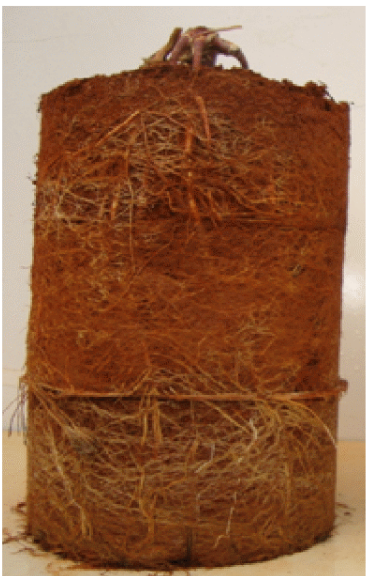

C.

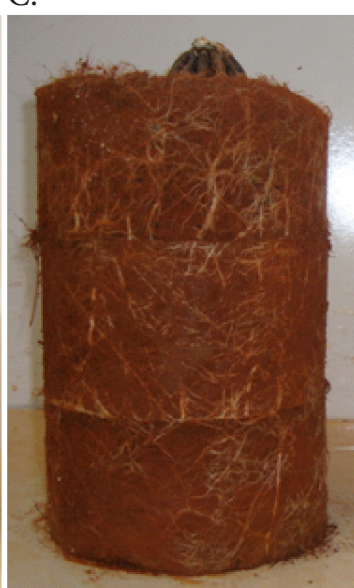

D.

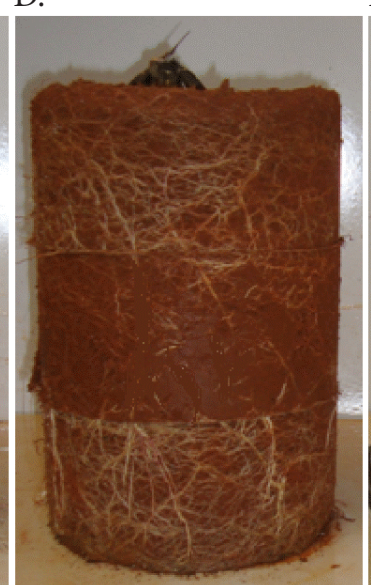

E.

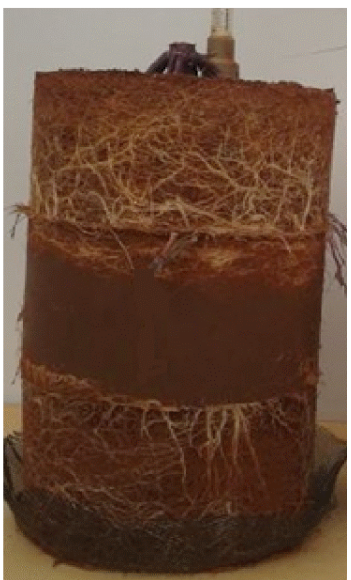

Figure 2. Distribution of roots in the soil profile of the experimental units at soil bulk densities of 1.0 (A), 1.2 (B), 1.4 (C), $1.6(\mathrm{D})$ and $1.8 \mathrm{Mg} \mathrm{m}^{-3}(\mathrm{E})$

Root production in the soil layer of $0.2-0.3 \mathrm{~m}$ occurred because thin roots are able to penetrate compacted soils more easily than thick ones, because roots do not penetrate pores with diameters smaller than theirs.

According to Foloni et al. (2003), the compacted layer in subsurface can modify root system distribution along the soil profile, but it did not decrease root production. However, Calonego et al. (2011) observed no influence of soil density on root production along the soil profile, for different crops, as also reported by Silva (2004), working with corn. The divergence of root data in the literature shows the difficulty to measure with precision the values of this variable.

According to Freddi et al. (2009b), the higher the root diameter, the greater will also be the force exerted in the process of elongation of root meristem cells to penetrate a certain soil layer. These authors reported difference in the development of corn roots in the layer of 0.0-0.2 m, while no difference was observed in the layer of $0.2-0.3 \mathrm{~m}$ for the variable root dry matter production.

The production of roots between the three soil layers was significantly influenced by soil bulk density and the applied water tensions in opposite ways; in the layers in which soil bulk density caused differences in root dry matter production, no effect of water tensions was observed.

According to the profile of the experimental unit, soil water tensions influenced root dry matter production only in the layer of 0.0-0.1 m, according to the equation $\mathrm{RDM}=24.0925$ - $0.1060 \mathrm{~T}$, with $\mathrm{R}^{2}=0.539$. Likewise, there was significant difference in the dry matter of adventitious roots (Figure $3 \mathrm{~A}$ ) and total root dry matter (Figure 3B). Thus, all these variables of root dry matter fitted to a decreasing linear regression model, showing that root production in the superficial soil layer, of adventitious roots and total roots of corn, was susceptible to the increase in irrigation intervals.

In this study, it was observed that the values of resistance to penetration of 2.22 and $6.76 \mathrm{MPa}$ reduced the dry matter production of adventitious roots by 26.12 and $34.83 \%$, respectively. Rosolem et al. (1999) found that the production of adventitious roots in corn plants was influenced by the levels of soil bulk density; however, they concluded that a resistance to penetration above $1.3 \mathrm{MPa}$ reduced the production of

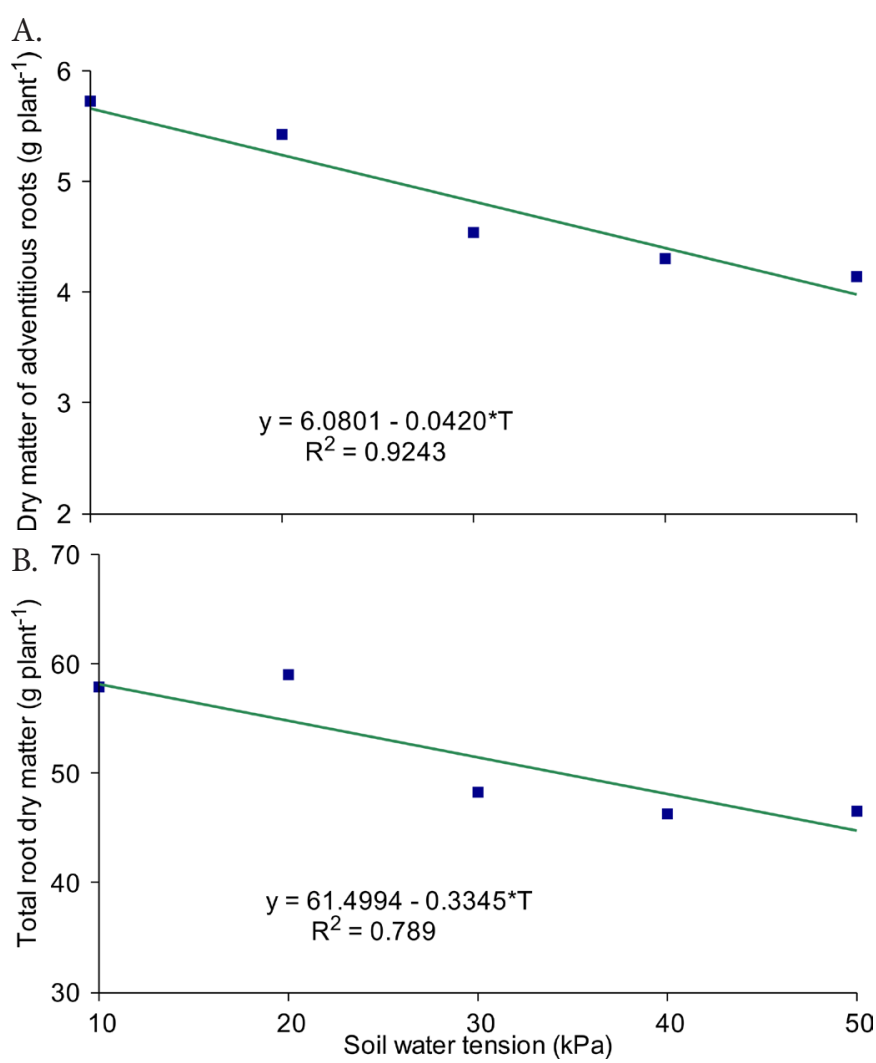

Figure 3. Dry matter of adventitious roots $(A)$ and total root dry matter $(B)$, as a function of soil water tensions

adventitious roots by half. Still diverging from the results of the present study, these authors observed that soil water tensions ranging from 3 to $64 \mathrm{kPa}$ did not influence root growth, but Veen \& Boone (1990) noted that the growth rate of both primary roots and adventitious roots were influenced by soil water tensions from 10 to $63 \mathrm{kPa}$, and adventitious roots were more sensitive.

The volume of water supplied to plants through irrigation probably did not infiltrate homogeneously in the entire soil profile of the experimental unit, because the superficial layer remained more humid than the underlying ones. This may have resulted in different resistances to penetration of roots in the soil due to soil moisture and density, since water is one of the factors that regulate root growth and distribution (Barber et al., 
1988) and the reduction in macroporosity has great effect on water infiltration velocity and root development, because they cause low aeration conditions in the soil (Freddi et al., 2009b).

Root production was significantly affected in the layer of 0.0-0.1 $\mathrm{m}$, probably because the replenished water volume did not infiltrate homogeneously in the entire soil profile, concentrating in the most superficial layer, which resulted in the highest root production in this layer, in all the evaluated treatments. According to Rosolem et al. (1999), soil water content affects the relationship between soil resistance to penetration and root elongation. These authors evaluated root growth as a function of water tensions applied in corn seedlings and observed no influence on the production of adventitious roots. However, they demonstrated that soils with more than $40 \%$ of clay show greater variation of resistance to penetration.

Likewise, Costa et al. (2008) observed results similar to those of the present study, working with two corn cultivars (BR106 and M-21) subjected to water stress levels. These authors observed no significant difference in relation to root dry matter production, regardless of the cultivar or the phenological stage. Conte et al. (2009) also observed no significant effect on root dry matter in the cultivation of irrigated and non-irrigated corn.

The supply of water to plants, besides reducing soil resistance to root penetration (Rosolem et al., 1999), helps in the control of plant temperature and absorption of nutrients, and in the ion-root contact through both mass flow and root interception and diffusion (Rosolem et al., 2003). Since there is no possibility of direct exchange between soil particles and plant roots, a liquid medium becomes essential, and these authors confirmed that an adequate supply, associated with good plant nutrition, tends to lead to greater exploration of soil by the root system.

\section{Conclusions}

1. In the soil layer of $0.0-0.1 \mathrm{~m}$, only the increase in water tension was a limiting factor for root production, with restriction for the increase of soil bulk density in the layer of 0.1-0.2 m.

2. The production of adventitious roots proved to be sensitive to the increase of bulk density and water tensions in the soil.

3. Soil densities higher than $1.21 \mathrm{Mg} \mathrm{m}^{-3}$ were limiting for root dry matter production in the layer of $0.2-0.3 \mathrm{~m}$ and total of roots.

\section{Literature Cited}

Barber, S. A.; Mackey, A. D.; Kuchenbuch, R. O.; Barraclough, S. Effect of soil temperature and water on maize root growth. Plant and Soil, v.111, p.267-269, 1988. http://dx.doi.org/10.1007/BF02139951

Bergamin, A. C.; Vitorino, A. C. T.; Lempp, B.; Souza, C. M. A.; Souza, F. R. Anatomia radicular de milho em solo compactado. Pesquisa Agropecuária Brasileira, v.45, p.299-305, 2010. http:// dx.doi.org/10.1590/S0100-204X2010000300010

Bonfim-Silva, E. M.; Monteiro, F. A. Nitrogênio e enxofre na adubação e em folhas diagnósticas e raízes do capim braquiária em degradação. Revista Brasileira de Zootecnia, v.39, p.1641-1649, 2010. http://dx.doi.org/10.1590/S1516-35982010000800004
Calonego, J. C.; Gomes, T. C.; Santos, C. H.; Tiritan, C. S. Desenvolvimento de plantas de cobertura em solo compactado. Bioscience Journal, v.27, p.289-296, 2011.

Conte, O.; Levien, R.; Trein, C. R.; Debiasi, H.; Mazuarana, M. Rendimento do milho em diferentes condições físicas de solo e quantidade de resíduo na ausência ou na presença de irrigação. Ciência Rural, v.39, p.1069-1076, 2009. http://dx.doi.org/10.1590/ S0103-84782009005000022

Costa, J. R.; Pinho, J. L. N.; Parry, M. M. Produção de matéria seca de cultivares de milho sob diferentes níveis de estresse hídrico. Revista Brasileira de Engenharia Agrícola e Ambiental, v.12, p.443450, 2008. http://dx.doi.org/10.1590/S1415-43662008000500001

Dourado Neto, D.; Nielsen, D. R.; Hopmans, J. W.; Reichardt, K.; Bacchi, O. O. S. Software to model soil water retention curves (SWRC, version 2.00). Scientia Agrícola, v.57, p.191-192, 2000. http://dx.doi.org/10.1590/S0103-90162000000100031

EMBRAPA - Empresa Brasileira de Pesquisa Agropecuaria. Manual de métodos de análises de solo. Centro Nacional de Levantamento e Conservação do Solo. Rio de Janeiro: Embrapa Solos. 1997. 212p.

EMBRAPA - Empresa Brasileira de Pesquisa Agropecuária. Reunião Técnica Anual de Milho, 58 e Reunião Técnica Anual de Sorgo, 41: Indicações técnicas para o cultivo de milho e de sorgo no Rio Grande do Sul safras 2013/2014 e 2014/2015. Brasília: EMBRAPA, 2013a. 124p.

EMBRAPA - Empresa Brasileira de Pesquisa Agropecuária. Sistema brasileiro de classificação de solos. 3.ed. Brasília. Embrapa. 2013b. 353p.

Foloni, J. S. S.; Calonego, J. C.; Lima, S. L. Efeito da compactação do solo no desenvolvimento aéreo e radicular de cultivares de milho. Pesquisa Agropecuária Brasileira, v.38, p.947-953, 2003. http:// dx.doi.org/10.1590/S0100-204X2003000800007

Freddi, O. S.; Centurion, J. F.; Beutler, A. N.; Aratani, R. G.; Leonel, C. L.; Silva, A. P. Compactação do solo e intervalo hídrico ótimo no crescimento e na produtividade da cultura do milho. Bragantia, v.66, p.477-486, 2007. http://dx.doi.org/10.1590/S000687052007000300015

Freddi, O. S.; Centurion, J. F.; Duarte, A. P.; Leonel, C. L. Compactação do solo e produção de cultivares de milho em Latossolo Vermelho. I - Características de planta, solo e índice $s$. Revista Brasileira de Ciência do Solo, v.33 p.793-803, 2009a. http://dx.doi.org/10.1590/ S0100-06832009000400005

Freddi, O. S.; Centurion, J. F.; Duarte, A. P.; Peres, F. S. C. Compactação do solo e produção de cultivares de milho em Latossolo Vermelho. II - Intervalo hídrico ótimo e sistema radicular. Revista Brasileira de Ciência do Solo, v.33 p.793-803, 2009b. http://dx.doi.org/10.1590/ S0100-06832009000400006

Genuchten, M. T. van. A closed form equation for predicting the hydraulic conductivity of unsaturated soils. Soil Science Society of America Journal, v.44, p.892-898, 1980. http://dx.doi.org/10.2136/ sssaj1980.03615995004400050002x

Jimenez, R. L.; Gonçalves, W. G.; Araújo Filho, J. V.; Assis, R. L.; Pires, F. R.; Silva, G. P. Crescimento de plantas de cobertura sob diferentes níveis de compactação em um Latossolo Vermelho. Revista Brasileira de Engenharia Agrícola e Ambiental. v.12, p.116121, 2008. http://dx.doi.org/10.1590/S1415-43662008000200002

Littell, R. C.; Mott, G. O. Computer assisted design and analysis of response surface experiments in agronomy. Soil and Crop Society of Florida Proceedings, v.34, p.94-97, 1975. 
Rivera-Hernández, B.; Carillo-Ávila, E.; Obrador-Olán, J. J.; JuárezLopez, J. F.; Aceves-Navarro, L. A.; García-López, E. Soil moisture tension and phosphate fertilization on yield components of A-7573 sweet corn (Zea mays L.) hybrid, in Campeche, Mexico. Agricultural Water Management, v.96, p.1285-1292, 2009. http:// dx.doi.org/10.1016/j.agwat.2009.03.020

Rosolem, C. A.; Fernandez, E. M.; Andreotti, M.; Crusciol, C. A. C. Crescimento radicular de plântulas de milho afetado pela resistência do solo à penetração. Pesquisa Agropecuária Brasileira, v.34, p.821-828, 1999. http://dx.doi.org/10.1590/S0100204X1999000500013

Rosolem, C. A.; Mateus, G. P.; Godoy, L. J. G.; Feltran, J. C.; Brancalião, S. R. Morfologia radicular e suprimento de potássio às raízes de milheto de acordo com a disponibilidade de água e potássio. Revista Brasileira de Ciência do Solo. v.27, p.875-884, 2003. http:// dx.doi.org/10.1590/S0100-06832003000500012

Severiano, E. C.; Oliveira, G. C.; Curi, N.; Dias Júnior, M. S. Potencial de uso e qualidade estrutural de dois solos cultivados com canade-açúcar em Goianésia, GO. Revista Brasileira de Ciência do Solo, v.33, p.159-168, 2009. http://dx.doi.org/10.1590/S010006832009000100017
Silva, G. J. Desenvolvimento de plantas de soja, milho, algodão e Brachiaria brizantha, submetidas a quatro graus de compactação de um Latossolo Vermelho-Escuro distrófico. Cuiabá: UFMT, 2004. 122p. Dissertação Mestrado

Souza, R. V. C. C.; Antunes, P. D.; Marques, M. C.; Freire, M. G. S. Influência de diferentes níveis de compactação e doses de fósforo no crescimento e nos teores de P na matéria seca de plantas milho (Zea mays L.) em um solo representativo do Estado de Pernambuco. Revista de Biologia e Ciências da Terra, v.8, p.94-100, 2008.

Streck, C. A.; Reinert, D. J.; Reichert, J. M.; Kaiser, D. R. Modificações em propriedades físicas com a compactação do solo causada pelo tráfego induzido de um trator em plantio direto. Ciência Rural, v.34 p.755760, 2004. http://dx.doi.org/10.1590/S0103-84782004000300016

Veen, B. W.; Boone, F. R. The influence of mechanical resistance and soil water on the growth of seminal roots of maize. Soil and Tillage Research, v.16, p.219-226, 1990. http://dx.doi.org/10.1016/01671987(90)90031-8

Wang, D.; Kang, Y.; Wan, S. Effect of soil matric potential on tomato yield and water use under drip irrigation condition. Agricultural Water Management, v.87, p.180-186, 2007. http:// dx.doi.org/10.1016/j.agwat.2006.06.021 